\title{
MONOCYTE DISTRIBUTION WIDTH; CAN IT BE USED AS AN EARLY DIAGNOSIS MARKER IN CASES OF ACUTE COMPLICATED APPENDICITIS? A PRELIMINARY STUDY
}

\author{
MONOSITT DAĞILIM GENİ̧LIĞİ AKUT KOMPLIKKE APENDİSITT OLGULARINDA ERKEN \\ TANI BELIRTECI OLARAK KULLANILABİLİR Mİ? ÖN ÇALIŞMA
}

Koray KOSMAZ ${ }^{1}$, Abdullah DURHAN ${ }^{1}$, Abdullah SENLIKCI ${ }^{1}$, Marlen SULEYMAN ${ }^{1}$, Can ERSAK ${ }^{1}$, Ender ERGUDER ${ }^{1}$, Yusuf Murat BAG ${ }^{2}$, Mehmet SENES ${ }^{3}$, Mevlüt Recep PEKCICI ${ }^{1}$

\begin{abstract}
AIM: The aim of this study was to investigate the effectiveness of monocyte distribution width in both the diagnosis of acute appendicitis (AA) and in differentiating between simple appendicitis (SA) and complicated appendicitis (CA).

MATERIAL AND METHOD: This study was conducted using data from 107 adult patients who underwent appendectomy. Demographic details, preoperative white blood cell (WBC) count, immature granulocyte count (IG) and percentage (IG \%), monocyte distribution width (MDW), neutrophil-lymphocyte ratio (NLR) and pathology results were evaluated retrospectively. Patients were grouped as AA and normal appendix (NA) according to the pathology reports, and the AA cases were divided into SA and CA groups according to the intraoperative findings.
\end{abstract}

RESULTS: WBC, IG, IG\%, NLR and MDW values were found to be statistically significant for the differentiation of acute appendicitis from normal appendicitis cases $(p<0.05)$. Of these parameters, the strongest parameter for the diagnosis of AA was NLR (sensitivity: $76 \%$, specificity: $89 \%, \mathrm{p}<0.001$ ). The IG value was found to be statistically significant in the diagnosis of complicated appendicitis cases $(\mathrm{p}<0.05)$

CONCLUSION: The MDW value is a fast, reliable and easily accessible parameter in the diagnosis of AA. However, although MDW values were found to be high in CA cases in the differentiation of SA and CA, they were not statistically significant. More comprehensive studies are needed for a clearer assessment.

Keywords: Acute appendicitis; complicated appendicitis, monocyte distribution width

${ }^{1}$ SBÜ Ankara Training and Research Hospital,General Surgery Clinic, Ankara, Turkey

${ }^{2}$ SBÜ Van Training and Research Hospital General Surgery Clinic, Van, Turkey

${ }^{3}$ SBÜ Ankara Training and Research Hospital, Biochemistry Clinic, Ankara, Turkey

Geliş Tarihi / Submitted : Eylül 2021 / September 2021

Kabul Tarihi / Accepted : Aralık 2021 / December 2021
ÖZET

AMAÇ: Bu çalışmanın amacı, apandisit (AA) tanısında ve ayrıca basit apandisit (SA) ile komplike apandisit (CA) arasında ayırıcı tanıda monosit dağılım genişliğinin etkinliğini araştırmaktı.

GEREC VE YÖNTEM: Bu çalıșma, apandektomi yapılan 107 erişkin hastanın verileri kullanılarak gerçekleştirildi. Demografik detaylar, preoperatif beyaz kan hücresi (WBC) sayısı, inmatür granülosit sayısı (IG) ve yüzdesi ( IG \% ), monosit dağılım genişliği ( MDW ), nötrofil-lenfosit oranı (NLR) ve patoloji sonuçları geriye dönük olarak değerlendirildi. Hastalar patoloji raporlarına göre AA ve normal apendiks (NA) olarak gruplandı ve AA olguları intraoperatif bulgulara göre SA ve CA gruplarına ayrıldı.

BULGULAR: Akut apandisit ile normal apandisit olgularını birbirinden ayırt etmede WBC, IG, IG\%, NLR ve MDW değerleri istatiksel olarak anlamlı bulundu $(\mathrm{p}<0.05)$. Bu parametreler içerisinde AA tanısı için en güçlü parametre ise NLR olduğu görüldü (sensitivitesi : 76\%, spesifite : $89 \%, \mathrm{p}<0.001$ ). Komplike apandisit olgularının tanısında ise IG değeri istatiksel olarak anlamlı bulundu $(\mathrm{p}<0.05)$

SONUÇ: MDW, AA tanısında hızlı, güvenilir ve kolay ulaşılabilir bir parametredir. Ancak SA ile CA ayrımın da MDW değerleri CA olgularında yükseldiği görülse de istatiksel olarak anlamlı bulunmadı. Daha net bir değerlendirme için daha kapsamlı çalışmalara ihtiyaç vardır.

Anahtar Kelimeler: Akut apandisit; komplike apandisit, monosit dağılım genişliği

\begin{tabular}{ll}
\hline Sorumlu Yazar / Corresponding Author: & Yazar Bilgileri /Author Information: \\
Koray KOSMAZ & Koray KOSMAZ (ORCID: 0000-0003-2111-3162), \\
SBÜ Ankara Eğitim ve Araştırma Hastanesi, Genel Cerrahi Kliniği, Hacettepe Mah. & Abdullah DURHAN (ORCID: 0000-0002-5622-9678) E-mail: durhanabdullah@gmail.com, \\
Ulucanlar Cad, No: 89 , Altındağ, Ankara, Türkiye & Abdullah SENLIKCI (ORCID:0000-0002-4321-4004) E-mail: asenlikci94@hotmail.com, \\
Gsm: +905065362371 & Marlen SULEMAN (ORCID: 0000-0001-6979-4150) E-mail: ankara.trh@gmail.com, \\
E-posta: koraykosmaz@hotmail.com & Can ERSAK (ORCID: 0000-0002-9658-6063) E-mail: canersak_13@hotmail.com, \\
& Ender ERGUDER (ORCID: 0000-0001-5289-3718) E-mail: endererguder93@gmail.com, \\
& Yusuf Murat BAG (ORCID: 0000-0002-0159-9356) E-mail: endererguder93@gmail.com, \\
& Mehmet SENES (ORCID: 0000-0002-7924-5478) E-mail: senesmehmet@yahoo-com, \\
& Mevlüt Recep PEKCICI (ORCID: 0000-0002-5566-8134) E-mail: pekcici@yahoo.com \\
\hline
\end{tabular}




\section{INTRODUCTION}

The appendix vermiformis $(\mathrm{AV})$ is a narrow, blunt-ended tubular organ attached to the cecum. Inflammation of the AV is known as acute appendicitis, which is one of the most common inflammatory diseases of the gastrointestinal tract. Reduction in blood flow as a result of obstruction of the appendix lumen, mucosal ischemic damage, and infection due to bacterial growth play a role in the pathogenesis of acute appendicitis ( 1 ).

Despite the availability of several algorithms and grading systems for the diagnosis of appendicitis, which includes a history, physical examination, and laboratory results, appendicitis can still be easily overlooked ( 2 ).

In western countries, approximately $8 \%$ of the general population is at risk of having an appendectomy in their lifetime ( 3 ). The majority of acute appendicitis cases are uncomplicated appendicitis. Complicated appendicitis (CA) is seen in approximately $20 \%$ to $30 \%$ of cases, while this rate rises to $50 \%$ in elderly patients $(4,5)$. Acute complicated appendicitis is a serious problem that increases the risk of morbidity and mortality in the postoperative period, prolongs hospital stay and increases medical costs ( 6 ). Therefore, early diagnosis and treatment of CA is critical ( 7 ).

Researchers have previously studied data such as NLR, platelet (PLT) value, mean platelet volume (MPV), platelet distribution width (PDW), red cell distribution width (RDW), IG, and IG percentage to assess the accuracy of the diagnosis of acute or complicated appendicitis ( 8-11).

A feasibility study recently conducted at a single academic center found that acute changes in monocyte size, referred to as the monocyte distribution width (MDW), best distinguished sepsis from other acute illnesses in the emergency department (e.g., compared to neutrophil volume changes), and that the combined performance of MDW and WBC for early sepsis detection was superior ( 12 ).

In the light of these studies to determine the severity of sepsis, the aim of this retrospective study was to evaluate whether MDW could play a role in the identification of patients with acute complicated appendicitis.

\section{MATERIAL AND METHOD}

The study included 107 adult patients who underwent appendectomy with a prediagnosis of acute appendicitis (AA) at xxx General Surgery Clinic between January 2019 and March 2020. Patients under the age of 18 years, pregnant women, and those with hematological comorbidities that may affect inflammatory markers were excluded from the study.

The demographic data, laboratory values and pathology results of the patients included in the study were retrieved from the hospital database records and analyzed. After a clinical history and abdominal examination, the complete blood count (CBC) of patients who presented at the Emergency Department with acute abdominal discomfort was assessed in patients with suspected AA. WBC, neutrophil, lymphocyte, and MDW levels were determined using an automated hematological analyzer (XN 3000; Sysmex Corp., Kobe, Japan) from blood samples drawn in the Emergency Department prior to surgery. The NLR, IG, IG percentage, and MDW values were derived using the $\mathrm{CBC}$ analysis results.

The patients in the research were classified into two groups based on their pathology reports: acute appendicitis and normal appendicitis (NA; negative appendectomy). Acute appendicitis patients were divided into two categories: simple appendicitis (SA) and complicated appendicitis (CA) (gangrenous, perforated and abscess). Preoperative laboratory results and demographic data were statistically evaluated and compared.

\section{Statistical Analysis}

Data obtained in the study were analyzed statistically using IBM SPSS Statistics for Windows, version 25.0 software (IBM Corp., Armonk, N.Y., USA). The normality of the distribution of numerical variables was analyzed with the Shapiro-Wilk test. Normally distributed numerical variables were given as mean \pm standard deviation (SD) values and were analyzed with the Student's t-test. Nonnormally distributed numerical variables were given as median (minimum-maximum) values and were analyzed with the Mann-Whitney U test. Categorical variables were expressed as frequency (n) and percentage (\%) and were assessed using the Chi-square test. Receiver operating characteristic (ROC) curves were created to determine the optimal cut-off value of continuous variables. A value of $p<0.05$ was considered statistically significant.

\section{RESULTS}

The demographic data, laboratory findings, and pathology results of the whole study group are summarized in Table 1 . The median age of the study group was 33 (17$80)$ years and $59.8 \%(n=64)$ of the patients were male. Pathological examinations revealed that $17.8 \%(n=19)$ of the patients who were operated on with the diagnosis of acute appendicitis had normal appendix. Of the 88 patients with pathologically proven acute appendicitis, 64 were evaluated as simple appendicitis and 24 as complicated appendicitis.

The results and comparisons between the acute appendicitis group and the normal appendix group are shown in Table 2. The male ratio was significantly higher in the AA group $(\mathrm{p}=0.006)$. In addition, higher WBC, IG , IG \%, MDW, and NLR values were determined in the AA group than in the normal appendix group $(\mathrm{p}=0.001$, $\mathrm{p}=0.008, \mathrm{p}=0.028, \mathrm{p}=0.005$, and $\mathrm{p}<0.001$ respectively).

The results and comparisons between the SA group and the CA group are presented in Table 3 . The patients in the CA group were significantly older (41.5 years vs 32 years, $\mathrm{p}=0.019$ ). From the laboratory findings, only the IG significantly differed between the groups and was 
higher in the CA group $(\mathrm{p}=0.045)$.

The ROC analyses of the predictors for AA and CA are shown in Table 4 and Table 5. All parameters were significantly able to predict AA and NLR was determined to be better than the other parameters with a cut-off value of 4.37 (AUC $=0.873$, sensitivity: $76 \%$, specificity: $89 \%$, $\mathrm{p}<0.001)$. The ability of IG to differentiate CA from SA was significant with a cut-off value of 0.07 ( $\mathrm{AUC}=0.639$, sensitivity: 58\%, specificity: 70\%, p<0.046).

Table 1.Demographic data, laboratory findings, and pathology results of the whole study group

\begin{tabular}{|l|l|}
\hline Age (years), median (min.-max.) & Study group (n=107) \\
\hline Gender (male), n (\%) & $64(17-80)$ \\
\hline WBC, median (min.-max.) & $14.92(5.14-35.00)$ \\
\hline IG, median (min.-max.) & $0.06(0.00-0.77)$ \\
\hline IG \%, median (min.-max.) & $0.40(0.00-2.20)$ \\
\hline MDW, mean + SD & $739.38 \pm 83.91$ \\
\hline NLR, median (min.-max.) & $6.25(1.02-38.58)$ \\
\hline $\begin{array}{l}\text { Pathology } \\
\text { Normal appendix, n (\%) }\end{array}$ & $19(17.8)$ \\
$\begin{array}{l}\text { Acuteappendicitis, n (\%) } \\
\text { Simple appendicitis, n (\%) } \\
\text { Complicatedappendicitis, n (\%) }\end{array}$ & $88(82.2)$ \\
\hline
\end{tabular}

Min: Minimum, Max: Maximum, SD: Standard deviation, WBC: White blood cell; IG: Immature granulocytes; IG\%: Immature granulocytes percentage; MDW:Monocyte distribution width; NLR: Neutrophil-to-lymphocyte ratio

Table 2.Results and comparisons of the demographic data and laboratory findings of the acute appendicitis group and the normal appendix group.

\begin{tabular}{|l|c|c|c|} 
& $\begin{array}{c}\text { Acute appendicitis } \\
(\mathbf{n = 8 8})\end{array}$ & $\begin{array}{c}\text { Normal appendix } \\
(\mathbf{n}=\mathbf{1 9})\end{array}$ & $\begin{array}{c}\mathbf{P} \\
\text { value }\end{array}$ \\
\hline Age (years), median (min.-max.) & $33.5(18-80)$ & $29(17-67)$ & 0.613 \\
\hline Gender (male), n (\%) & $58(65.9)$ & $6(31.6)$ & $\mathbf{0 . 0 0 6}^{\star}$ \\
\hline WBC, median (min.-max.) & $15.52(7.48-35.00)$ & $12.03(5.14-18.80)$ & $\mathbf{0 . 0 0 1}^{\star}$ \\
\hline IG, median (min.-max.) & $0.06(0.01-0.77)$ & $0.05(0.00-0.14)$ & $\mathbf{0 . 0 0 8}^{\star}$ \\
\hline IG \%, median (min.-max.) & $0.40(0.10-2.20)$ & $0.40(0.00-0.90)$ & $\mathbf{0 . 0 2 8}^{\star}$ \\
\hline MDW, mean + SD & $749.73 \pm 82.87$ & $691.42 \pm 72.92$ & $\mathbf{0 . 0 0 5}^{\star}$ \\
\hline NLR, median (min.-max.) & $7.21(1.43-38.58)$ & $2.53(1.02-6.45)$ & $<\mathbf{0 . 0 0 1}^{\star}$ \\
\hline
\end{tabular}

Min: Minimum, Max: Maximum, SD: Standard deviation, WBC: White blood cell; IG: Immature granulocytes; IG\%: Immature granulocytes percentage; MDW:Monocyte distribution width; *: Statistically significant

Table 3.Results and comparisons of the demographic data and laboratory findings of the simple appendicitis group and the complicated appendicitis group.

\begin{tabular}{|l|c|c|c|} 
& $\begin{array}{c}\text { Simple appendicitis } \\
(\mathbf{n = 6 4})\end{array}$ & $\begin{array}{c}\text { Complicated appendicitis } \\
(\mathbf{n = 2 4})\end{array}$ & $\begin{array}{c}\mathbf{P} \\
\text { value }\end{array}$ \\
\hline Age (years), median (min.-max.) & $32(18-60)$ & $41.5(22-80)$ & $\mathbf{0 . 0 1 9}^{*}$ \\
\hline Gender (male), n (\%) & $43(67.2)$ & $15(62.5)$ & 0.679 \\
\hline WBC, median (min.-max.) & $15.30(7.48-25.72)$ & $16.60(7.91-35.00)$ & 0.097 \\
\hline IG, median (min.-max.) & $0.06(0.01-0.15)$ & $0.08(0.02-0.77)$ & $\mathbf{0 . 0 4 5}^{\star}$ \\
\hline IG \%, median (min.-max.) & $0.40(0.10-1.00)$ & $0.50(0.20-2.20)$ & 0.064 \\
\hline MDW, mean + SD & $722.28 \pm 86.05$ & $765.62 \pm 73.04$ & 0.273 \\
\hline NLR, median (min.-max.) & $6.61(1.43-38.58)$ & $8.56(2.39-27.34)$ & 0.062 \\
\hline
\end{tabular}

Min: Minimum, Max: Maximum, SD: Standard deviation, WBC: White blood cell; IG: Immature granulocytes; IG \%: Immature granulocytes percentage; MDW:Monocyte distribution width; ${ }^{*}$ : Statistically significant 
Table 4. The ROC analysis of the predictors for acute appendicitis

\begin{tabular}{|c|c|c|c|c|c|c|c|}
\hline & AUC & $95 \%$ col & nce interval & $\begin{array}{l}\text { Cut- } \\
\text { offvalue }\end{array}$ & $\begin{array}{c}\text { Sensitivity } \\
(\%)\end{array}$ & $\begin{array}{c}\text { Specificity } \\
(\%)\end{array}$ & $P$ value \\
\hline & & $\begin{array}{l}\text { Lower } \\
\text { bound }\end{array}$ & Upper bound & & & & \\
\hline WBC & 0.735 & 0.609 & 0.862 & 14.855 & 0.580 & 0.789 & 0.001 \\
\hline IG & 0.694 & 0.554 & 0.835 & 0.055 & 0.648 & 0.684 & 0.008 \\
\hline IG \% & 0.656 & 0.517 & 0.796 & 0.450 & 0.386 & 0.842 & 0.033 \\
\hline MDW & 0.706 & 0.592 & 0.820 & 706.500 & 0.727 & 0.789 & 0.005 \\
\hline NLR & 0.873 & 0.801 & 0.946 & 4.373 & 0.761 & 0.895 & $<0.001$ \\
\hline
\end{tabular}

ROC: Receiver operating characteristics; AUC: Area under curve; WBC: White blood cell; IG: Immature granulocytes; IG \%: Immature granulocytes percentage; MDW:Monocyte distribution width

Table 5. The ROC analysis of the predictor for complicated appendicitis

\begin{tabular}{|c|c|c|c|c|c|c|c|}
\hline & AUC & $95 \%$ & dence & $\begin{array}{l}\text { Cut-off } \\
\text { value }\end{array}$ & $\begin{array}{c}\text { Sensitivity } \\
(\%)\end{array}$ & $\begin{array}{c}\text { Specificity } \\
(\%)\end{array}$ & $P$ value \\
\hline & & $\begin{array}{l}\text { Lower } \\
\text { bound }\end{array}$ & $\begin{array}{l}\text { Upper } \\
\text { bound }\end{array}$ & & & & \\
\hline IG & 0.639 & 0.495 & 0.783 & 0.075 & 0.583 & 0.703 & 0.046 \\
\hline
\end{tabular}

ROC: Receiver operating characteristics; AUC: Area under curve; IG: Immature granulocytes

\section{DISCUSSION}

An accurate acute appendicitis diagnosis is critical not only for lowering NA rates, but also for distinguishing severe appendicitis cases such as perforated appendicitis from uncomplicated appendicitis. Despite advancements in diagnostic methods and treatment, substantial incidence of NA and perforation are still observed today (13-36 \%, 12-21\%, respectively). Perforation rates are as high as $50 \%$ in older individuals, especially ( 13-15).

Patients with CA, such as perforation, have higher morbidity and mortality rates, longer hospital stays, and higher medical expenditure. Therefore, new biomarkers are required to lower the risk of both NA and CA. CRP is a well-known biomarker for predicting CA because the level rises 8-12 hours after the commencement of the inflammatory process and continues to rise for the next 24-48 hours. According to Moon et al., CRP is an independent predictor of CA ( 16 ). Abdelhalim et al. investigated the predictive value of combining WBC count, CRP, and bilirubin as biomarkers, and discovered that this combination had high specificity $(95 \%)$ for the diagnosis of acute and complex appendicitis [17]. WBC is a biomarker frequently utilized in the diagnosis of acute appendicitis. In a clinical study by Demircan et al., it was stated that WBC, other inflammatory markers, and abdominal ultrasonography and computed tomography of the abdomen were supportive tests in the diagnosis of acute appendicitis ( 18 ). Ertekin et al. showed that the WBC level is high in patients with acute appendicitis and $\mathrm{WBC}$ sensitivity was reported as $70 \%$ and specificity as $60 \%$ ( 19 ). In this study, WBC values were found to be high in AA patients with sensitivity of $58 \%$ and specificity of $78 \%$.

The physiological response of circulating leukocytes under stress is generally an increase in neutrophil count and a decrease in lymphocyte count. Therefore, the NLR of these 2 subgroups is used as an inflammation parameter. In a study by Kahramanca et al., NLR was determined to be a useful parameter in diagnosing AA and for differentiating between SA and CA ( 20 ). In the current study, NLR was found to be the strongest parameter in diagnosing AA.

As a result of technological developments in automated hematological analyzers, it is now feasible to identify the proportion and number of IG, and recent studies have demonstrated that IG may be employed as an efficient inflammatory marker $(21,22)$. However, in a trial with 403 patients, Park et al. discovered that the sensitivity of IG\% was insufficient for the diagnosis of AA and did not give any significant advantage when compared to other inflammatory markers ( 23 ). In contrast, another investigation comprising 438 patients reported that the IG value was a quick, easy-to-access, and reliable measure in both the diagnosis of AA and the differentiation of SA from CA ( 11 ). In the current study, IG \% and IG values were determined to be statistically significant in the diagnosis of AA. The IG value was likewise discovered to be the sole statistically significant measure in differentiating between SA and CA.

Neutrophils and monocytes in the plasma are the initial line of defence against pathogenic microorganisms. Recent research has demonstrated that increased immune cell volume can be used to diagnose sepsis. Crouser et al. demonstrated that combining MDW and WBC might be utilized to diagnose sepsis ( 24 ). In another study, Crouser et al. stated that MDW might be useful in the early detection of sepsis in the Emergency Department (25). According to a recent study by Ognibene et al., MDW might be utilized 
as an indication of sepsis in COVID-19 patients ( 26 ). The MDW values were shown to be statistically significant in diagnosing AA in the current study, and although MDW values were greater in CA cases than in SA, the difference was not statistically significant.

\section{CONCLUSION}

In conclusion, WBC, NLR, IG, IG\%, and MDW levels are criteria that can be utilized to diagnose AA. The IG value was shown to be more beneficial than other criteria in the diagnosis of CA. However, this was preliminary research testing the use of MDW value in the diagnosis of CA patients, and there is a need for further studies with larger patient populations to provide a more accurate assessment.

\section{STATEMENT OF AUTHOR CONTRIBUTIONS $\mathrm{KK}, \mathrm{AD}, \mathrm{AS}$ : Work management, article writing, background assessment, literature review, final decision MS, CE, EE: Design, article writing, literature review YMB, MŞ, MRP: Statistics, literature review}

Acknowledgement: None.

Conflict of Interest: None. No competing financial interests exist.

\section{REFERENCES}

1.)Becker K, Höfler H. Pathology of appendicitis. Chirurg 2002;73:777-81.

2.)Narci H, Turk E, Karagulle E, et al. The role of red cell distribution width in the diagnosis of acute appendicitis: a retrospective casecontrolled study. World J Emerg Surg. 2013;8:46.

3.)Nshuti R, Kruger D, Luvhengo TE. Clinical presentation of acute appendicitis in adults at the Chris Hani Baragwanath Academic Hospital. Int J Emerg Med 2014;7:12.

4.)Franz MG, Norman J, Fabri PJ. Increased morbidity of appendicitis with advancing age. Am Surg 1995;61:40

5.) Yamini D, Vargas H, Bangard F, et al. Perforated appendicitis: is it truly a surgical urgency? Am Surg 1998;64:970-5.

6.)Lee JF, Leow CK, Lau WY. Appendicitis in the elderly. ANZ J Surg 2000;70:593-6.

7.)Lunca S, Bouras G, Romedea NS. Acute appendicitis in the elderly patient:diagnostic problems, prognostic factors and outcomes. Rom J Gastroenterol 2004;13:299-303.

8.)Senlikci A, Guven R. Prognostic Value of Neutrophil / Lymphocyte Ratio and Mean Platelet Volume Value in the Diagnosis of Acute Appendicitis. Surg Chron 2018; 23: 167-9.

9.)Boshnak N, Boshnaq M, Elgohary H. Evaluation of Platelet Indices and Red Cell Distribution Width as New Biomarkers for the Diagnosis of Acute Appendicitis. J Invest Surg. 2018;31:121-9.
10.)Sepas HN, Negahi A, Mousavie SH, et al. Evaluation of the Potential Association of Platelet Levels, Mean Platelet Volume and Platelet Distribution Width with Acute Appendicitis. Maced J Med Sci. 2019;7:2271-6.

11.)Unal Y. A new and early marker in the diagnosis of acute complicated appendicitis: immature granulocytes. Ulus Travma Acil Cerrahi Derg. 2018;24:434-9.

12.)Crouser ED, Parrillo JE, Seymour CW, et al. Monocyte Distribution Width: A Novel Indicator of Sepsis-2 and Sepsis-3 in High-Risk Emergency Department Patients. Crit Care Med. 2019;47:1018-25.

13.)Broker ME, van Lieshout EM, van der Elst $M$, et al. Discriminating between simple and perforated appendicitis. J Surg Res 2012;176:79-83 14.)Sevinc MM, Kınacı E, Cakar E, et al. Diagnostic value of basic laboratory parameters for simple and perforated acute appendicitis: an analysis of 3392 cases. Ulus Travma Acil Cerrahi Derg 2016;22:155-62. 15.)Shin DH, Cho YS, Kim YS, et al. Delta neutrophil index: a reliable marker to differentiate perforated appendicitis from non-perforated appendicitis in the elderly. J Clin Lab Anal. 2018;32:e22177

16.)Moon HM, Park BS, Moon DJ. Diagnostic value of C-reactive protein in complicated appendicitis. J Korean Soc Coloproctol. 2011;27:122-6.

17.)Abdelhalim MA, Stuart JD, Nicholson GA. Augmenting the decision making process in acute appendicitis: a retrospective cohort study. Int J Surg. 2015;17:5-9.

18.)Demircan A, Aygencel G, Karamercan M, et al. Ultrasonographic findings and evaluation of white blood cell counts in patients undergoing laparotomy with the diagnosis of acute appendicitis. Ulus Travma Acil Cerrahi Derg 2010; 16: 248-52.

19.)Ertekin B, Kara H, Erdemir E, et al. Efficacy of Use of Red Cell Distribution Width as a Diagnostic Marker in Acute Appendicitis. Eurasian J Emerg Med 2017; 16: 29-33.

20.)Kahramanca S, Ozgehan G, Seker D, et al. Neutrophil-tolymphocyte ratio as a predictor of acute appendicitis. Ulus Travma Acil Cerrahi Derg 2014;20:19-22

21.)Senthilnayagam B, Kumar T, Sukumaran J, et al. Automated measurement of immature granulocytes: performance characteristics and utility in routine clinical practice. Pathol Res Int 2012;2012:483670 22.)Mathews EK, Griffin RL, Mortellaro V, et al. Utility of immature granulocyte percentage in pediatric appendicitis. J Surg Res 2014;190:230-4.

23.)Park JS, Kim JS, Kim YJ, et al. Utility of the immature granulocyte percentage for diagnosing acute appendicitis among clinically suspected appendicitis in adult. J Clin Lab Anal. 2018;32:e22458.

24.) Crouser ED, Parrillo JE, Seymour C, et al. Improved Early Detection of Sepsis in the ED With a Novel Monocyte Distribution Width Biomarker. Chest. 2017;152:518-26.

25.)Crouser ED, Parrillo JE, Martin GS, et al. Monocyte distribution width enhances early sepsis detection in the emergency department beyond SIRS and qSOFA. J Intensive Care. 2020;8:33.

26.) Ognibene A, Lorubbio M, Magliocca $P$, et al. Elevated monocyte distribution width in COVID-19 patients: The contribution of the novel sepsis indicator [published online ahead of print, 2020 Jun 3]. Clin Chim Acta. 2020;509:22-4

\footnotetext{
Ankara Eğt. Arş. Hast. Derg. (Med. J. Ankara Tr. Res. Hosp.), 2021 ; 54(3) : 424-428

S.B.Ü. Ankara Eğitim ve Araştırma Hastanesi Klinik Araştırmalar Etik Kurulu'nun 06.07.2021 tarih ve 648/2021 sayılı izni ile yürüttïlmüştür.
} 